\title{
COVID-19 one year into the pandemic: from genetics and genomics to therapy, vaccination, and policy
}

\author{
Giuseppe Novelli ${ }^{1,2,3^{*}}$ D, Michela Biancolella ${ }^{4}$, Ruty Mehrian-Shai ${ }^{5}$, Vito Luigi Colona ${ }^{1}$, Anderson F. Brito ${ }^{6}$, \\ Nathan D. Grubaugh ${ }^{6}$, Vasilis Vasiliou ${ }^{7}$, Lucio Luzzatto ${ }^{8}$ and Juergen K. V. Reichardt ${ }^{9}$
}

\begin{abstract}
COVID-19 has engulfed the world and it will accompany us all for some time to come. Here, we review the current state at the milestone of 1 year into the pandemic, as declared by the WHO (World Health Organization). We review several aspects of the on-going pandemic, focusing first on two major topics: viral variants and the human genetic susceptibility to disease severity. We then consider recent and exciting new developments in therapeutics, such as monoclonal antibodies, and in prevention strategies, such as vaccines. We also briefly discuss how advances in basic science and in biotechnology, under the threat of a worldwide emergency, have accelerated to an unprecedented degree of the transition from the laboratory to clinical applications. While every day we acquire more and more tools to deal with the on-going pandemic, we are aware that the path will be arduous and it will require all of us being community-minded. In this respect, we lament past delays in timely full investigations, and we call for bypassing local politics in the interest of humankind on all continents.
\end{abstract}

Keywords: Coronavirus, SARS-CoV-2, COVID-19, Pandemic, Variants, Vaccines, Monoclonal antibodies, Politics

\section{Introduction}

The coronavirus disease 2019 (COVID-19), caused at individual level by the severe acute respiratory syndrome coronavirus 2 (SARS-CoV-2), has raged for a year now, as declared by the WHO (World Health Organization) [1]. By March 31, 2021, more than 125 million cases of SARS-CoV-2 infection have been reported, causing 2, 816,081 deaths in 192 countries (Johns Hopkins University, CSSE). About the Coronavirus Treatment Acceleration Program (CTAP), there are more than 590 drug development programs in planning stages (i.e., antivirals, immunomodulators, cell and gene therapies, compound combinations and other active principles, vaccines

\footnotetext{
* Correspondence: novelli@med.uniroma2.it

'Department of Biomedicine and Prevention, "Tor Vergata" University of Rome, 00133 Rome, Italy

${ }^{2}$ IRCCS Neuromed, Pozzilli, IS, Italy

Full list of author information is available at the end of the article
}

excluded), more than 430 clinical trials reviewed by FDA (Food and Drug Administration) with a total of 9 COVID-19 treatments currently approved for use under Emergency Use Authorization (EUA) (https://www.fda. gov/drugs/coronavirus-covid-19-drugs/coronavirustreatment-acceleration-program-ctap, accessed on March 31, 2021) [2]. Due to socioeconomic inequalities, such clinical trials are mainly conducted in/by institutions in high income countries. Disparities also impose large limitations on low/mid income countries, which are often unable to cope with high demands for molecular testing, variant surveillance, vaccine distribution, or to address the needs of their citizens for financial aid, to survive amid tough epidemic control measures. This shows that the effects of this pandemic may well be farreaching and long-lasting. The central role and responsibility of the UN (United Nations) and specifically of the WHO are paramount. The very word pandemic means 
that it cannot be confronted by measures that are only at the level of a region, or of a country, or even of a continent: global measures are absolutely needed.

\section{On the origin of the COVID-19 pandemic}

We note that last year already the WHO set up a panel to investigate the origin, preparedness, and response to the COVID-19 pandemic (https://www.who.int/news/ item/09-07-2020-independent-evaluation-of-globalcovid-19-response-announced) [3]. Regrettably, there has been only limited progress and the origin of the pandemic has not been definitively pinned down (https:// www.sciencemag.org/news/2021/03/compromise-whoreport-resolves-little-pandemic-s-origins-details-probe-snext-steps) [4]. All of us, whether directly affected patients or not, should be concerned by such astounding delays, since it is of immense common interest for all to be best prepared for the next pandemic that will inevitably befall us eventually. We lament these delays and we call for expeditious, effective, and scientifically rigorous action by the WHO and the UN. We are not suggesting that these delays are politically motivated: but we are anxious for these organizations to show clear evidence that they are driven at all times by their feeling of responsibility toward all humankind. As scientists who are also citizens from around the world, we wish to be able to say that they are now acting more nimbly and selfassuredly. We also wish to highlight the importance of being mindful that emerging nations that will need thoughtful assistance in order to face the immediate health crisis, as well as the economic recovery thereafter: they need improved and more resilient health systems on a medium to long-term basis, as well as food security. In this context, a critical role should be played by other international organizations such as the EU (European Union) and notably the FAO (Food and Agriculture Organization of the UN). However, other regional organizations, such as ASEAN (Organization of Southeast Asian States), the AU (African Union), and the OAS (Organization of American States), should also play a significant and culture-sensitive role in their respective geographic areas.

\section{Virus variants}

An important reason of concern for all countries is the emergence of virus variants as a result of mutation(s) during the current pandemic. RNA viruses, such as SARS-CoV-2, despite being endowed with proofreading activity during viral replication [5], have a high mutation rate, and the absolute number of mutations increases with every round of infection [6]. The average evolutionary rate of SARS-CoV-2 is $\sim 0.8 \times 10^{-4}$ substitutions per site per year, which equals about 2 substitutions ("mutations") per month. Mutations that are deleterious or even lethal to the virus will be purged from the population, and we do not need to worry about those. Many mutations are essentially neutral, and are maintained in the population: they may not readily promote functional changes, but they may facilitate adaptation upon changes in the environment explored by viruses $[7,8]$. However, a few mutations may be beneficial to the virus [9] because they lead to (i) increased transmissibility; (ii) higher infectiousness, (iii) higher virulence entailing higher rate of severe disease; (iv) immune/vaccine escape; or (v) any combination of the above.

Up to March 31, 2021, nearly 1 million $(931,463)$ SARS-CoV-2 genomic sequences were submitted to the GISAID, the main database used by researchers in the field (https://www.gisaid.org) [10] (Fig. 1, Table S1). SARS-CoV-2 variants identified are heterogeneously distributed in geographic areas of the world (see https:// nextstrain.org/ncov/global) [11, 12]. Variants of SARS$\mathrm{CoV}-2$ may adapt differently to the host under individual selective pressures [7]; some mutations may increase in frequency, either through genetic drift or through selection, and become fixed in different populations $[6,7]$. This is the case of the mutation that led to the amino acid change D614G (Asp614 $\rightarrow$ Gly) in the spike glycoprotein (S), found in the predominant form of SARSCoV-2 $[13,14]$. Patients infected with the D614G variant often have higher viral loads in the upper respiratory tract than seen with the ancestral strain, but there seems to be no difference in disease severity [15]. The D614G mutation determines an important conformational change in the spike protein between the S1 and S2 domains, that favors the binding to the angiotensinconverting enzyme 2 (ACE2) receptor and thus increases the probability of infection: presumably the key to this variant having become globally dominant [15]. Recently, Huang et al. [13] have attributed the selective advantage of D614G variant to the quantitative differences in ACE2 expression in different populations. The lower ACE2 expression observed in the European, North American, and African populations, compared to Asians, may have driven positive selection favoring the D614G mutation.

Many SARS-CoV-2 mutations appeared and were selected for several times, independently, e.g., those that changes the asparagine residue at spike position 501 (S: N501Y, S:N501T, S:N501S). This residue is within the receptor-binding domain (RDB), that is important for both binding to ACE2 and for antibody recognition. A variant with S:N501Y, B.1.1.7 (also known as 20B/ 501Y.V1), was announced in the South East of England on December 14, 2020 [14]. Variants from this particular lineage are associated with multiple amino acid changes in the spike protein, including a deletion at 69/70 [16], Y144 deletion, and $\mathrm{P} 681 \mathrm{H}$ (adjacent to the furin cleavage 


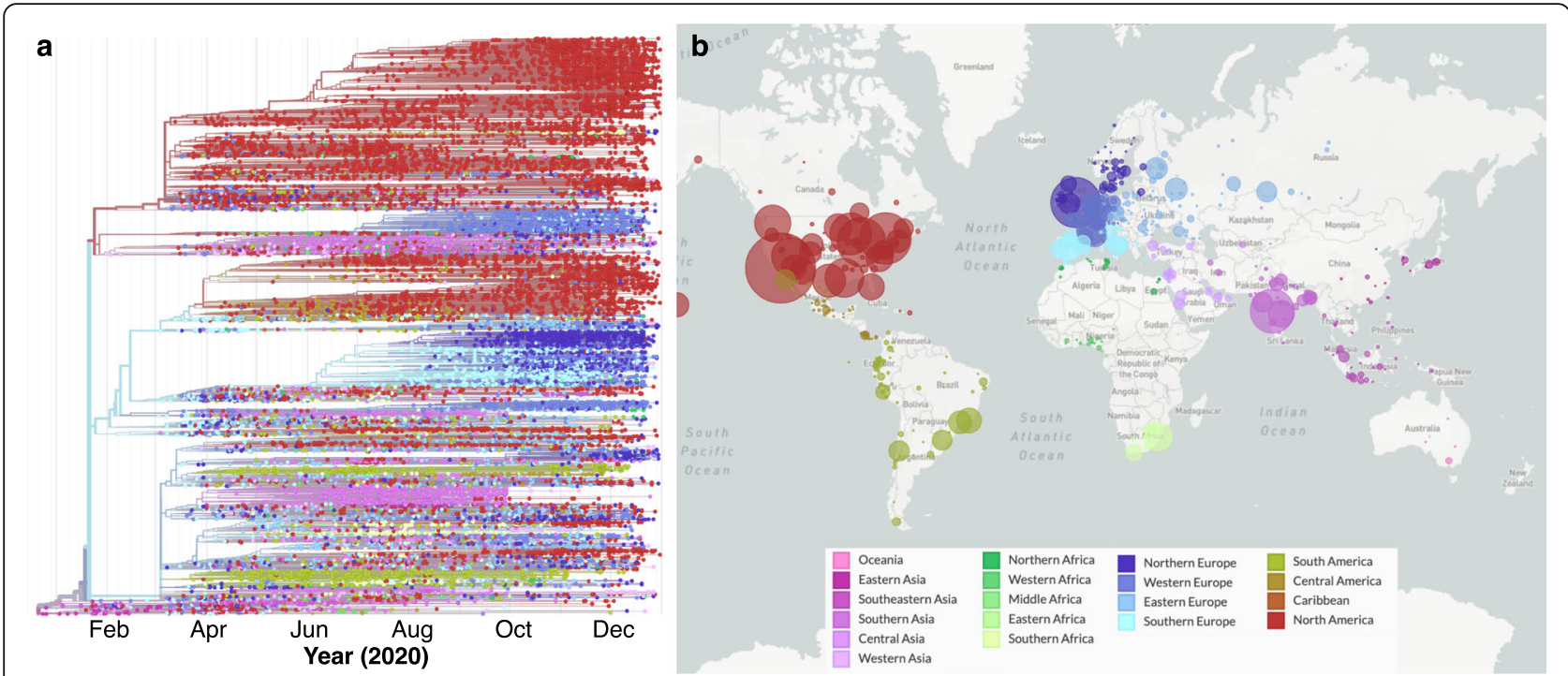

Fig. 1 SARS-CoV-2 genomic surveillance. a Phylogenetic tree of 19,438 SARS-CoV-2 genomes. Up to December 31, 2020, more than 295,000 complete genomes were submitted to the GISAID database. Each circle in this tree represents a genome that was sequenced over time, since the beginning of the pandemic. As SARS-CoV-2 establishes new infections, its descendants form lineages of genetically related viruses, which can circulate more locally, as shown in lineages represented by threads of circles with similar colors (as shown in red, at the top of panel a), or may have more heterogeneous distributions, as depicted in lineages with multiple colors, highlighting the exchange of viruses between geographic regions (as shown at the bottom of panel a). b State level distribution of SARS-CoV-2 genomes shown in panel a (see acknowledgement Table S1). All regions of the world were impacted by the pandemic, some more than others. As a result, an imbalance in the distribution of genomes worldwide (depicted in panel $\mathbf{b}$ as bubbles of distinct sizes) is evident. The differences in genome sampling across continents and countries may not only be the result of epidemic control via distinct public health strategies (as observed in New Zealand and Australia, for example) but may also result from socioeconomic disparities at national and international scales, where some regions (e.g., South and Central America, most regions in Africa), despite being hard hit by the pandemic, are unable to conduct genomic surveillance at a scale comparable to that of rich countries in North America and Europe. Analyses and illustrations were respectively generated using augur and auspice (by nextstrain.org) [11]

site). Rapidly spreading variants were also detected in South Africa. Viruses belonging to the lineage B.1.351 (also known as 20H/501Y.V2) were detected in December 2020 [17]. These variants are associated with multiple amino acid changes in spike protein, including $\mathrm{S}$ : N501Y, S:K417N, and S:D80A, but they do not have the deletion at $69 / 70$ (Table 1). After the detection of these variants harboring similar genetic changes, genomic surveillance in countries experiencing high COVID-19 incidence started to report more variants with convergent genetic traits. In late 2020, a new variant was detected in Manaus, state of Amazonas, northern Brazil [18]. The new lineage, named P.1 (descendant of B.1.1.28, also known as 20J/501Y.V3), contains a unique constellation of lineage-defining mutations, including several amino acid changes of biological significance known as S: E484K, S:K417T, and S:N501Y. The P.1 lineage was identified in $42 \%$ (13 of 31 ) of RT-PCR positive samples collected between 15 and 23 December 2020, but was absent in 26 publicly available genome surveillance samples collected in Manaus between March and November 2020. These results indicate local transmission and possibly a recent increase in the frequency of a new lineage from the Amazon region [18]. Finally, two lineages originated in California, USA, have also emerged and increased in frequency from late 2020 to early 2021, named B.1.427 and B.1.429, both showing three amino acid substitutions: S:S13I, S:W152C, and S:L452R [19]. Variants from these two lineages have higher transmissibility (from 18.6 to $24 \%$ ) when compared with wild type variants.

Some of the variants of concern have not only been associated with increased transmission potential but also with reduced susceptibility to neutralizing antibodies

Table 1 Important variants of SARS-CoV-2 that emerged in late 2020

\begin{tabular}{llll}
\hline Lineage & Other designations & Likely origin & Key genetic changes \\
\hline B.1.1.7 & 20l/501Y.V1 & UK & 69-70del, 144del, S:N501Y \\
B.1.351 & 20H/501Y.V2 & South Africa & S:E484K, S:N501Y \\
P.1 & 20J/501Y.V3 & Brazil & S:E484K, S:N501Y \\
\hline
\end{tabular}

Evidence from epidemiological and in vitro assays suggests that variants bearing the key genetic changes listed below are more transmissible 
from convalescent patients and vaccines (immune scape) [20]. However, it is important to point out that cellular response conferred by vaccines is robust, identifies epitopes from many proteins beyond the Spike, and major losses of vaccine efficacy would mainly come as a cumulative effect of several widespread genetic changes that SARS-CoV-2 undergoes as it continues to spread [21]. Another important consequence of mutations is phenotypic changes of virulence. Initial studies have been suggesting that some variants may cause more severe illness, as already reported for B.1.1.7 [19, 22].

The emergence of SARS-CoV-2 variants with concerning phenotypes underscores the importance of genomic surveillance. The ability to track the spread of variants differs dramatically across regions, both in international and national levels [23, 24]. To prevent unnoticed viral spread, and to be able to promptly respond to new variants as they emerge, genomic surveillance needs to be incorporated as a routine activity by local departments of public health, sequencing a minimum percent of reported cases (1-5\% of cases or more) per administrative division (towns, cities, counties, state, etc.).

\section{Human genetic susceptibility}

Like in all infectious diseases, while pathogen genetics plays an important role, host genetics and physiology are key elements in determining the clinical course of disease in COVID-19 patients. The main unspecific symptoms of the disease are fever, myalgia, fatigue, and dry cough. As known, SARS-CoV-2 first affects the respiratory tract and then activates a systemic inflammatory response that can lead to interstitial pneumonia, up to more critical conditions. The worldwide infection fatality rate (IFR) is currently estimated around $2-3 \%$, with a variability depending on different genetic and nongenetic factors, like sex and age above all [25]. It is a matter of fact that environmental factors contribute to the disease severity, but the health status represents a background that should not be underestimated.

\section{Comorbidities}

Virus-host interaction plays a fundamental role in the disease's outcome. Although most patients have a favorable prognosis, some groups are at higher risk, or "extremely vulnerable" to severe illness. These include first and foremost individuals with impaired immune system function; but also those with cancer, severe lung disease, such as chronic obstructive pulmonary disease (COPD), and pregnant women with cardiological disease [26, 27]. At "high risk" are also older patients, very obese individuals with obstructive sleep apnea syndrome (OSAS), and those with diabetes mellitus, neurological disorders, or heart, lung, liver, and kidney diseases, who are especially vulnerable to virus-induced acute respiratory distress syndrome (ARDS) [28]. This general risk stratification has exceptions: even young people without comorbidity may develop severe disease that may even become fatal. In order to explain this, several hypotheses have been formulated, including breakdown of immunological tolerance, the viral load, an innate immune inefficiency, and the presence of common or rare risk alleles in genes encoding proteins important for the biological cycle of the virus $[29,30]$. A deeper knowledge of the involvement of the alterations affecting these pathways and the innate and adaptive immune system may represent a turning point for understanding the pathophysiological mechanisms of SARS-CoV-2 and the development of new therapeutic strategies. Variants in the genes that encode these proteins could contribute to different responses to infections.

\section{Genetic factors}

Common and rare variants have been identified in different studies using different approaches (Table 2): Genome wide association studies (GWAS) and deep sequencing in selected cohorts and/or large biobank resources [35, 4550]. Association studies made it possible to identify in a number of genes susceptibility alleles for severe disease phenotypes: however, so far, the risk values are too low $(\mathrm{OR}<2)$ to be regarded as predictive genomic markers (Table 2). Nonetheless, the additive effects of this low penetrance alleles might become important in the future through polygenic scores analysis [51]. On the other hands, highly penetrance alleles of genes encoding proteins involved in important pathways such as those of innate immunity (e.g., TLR3, IRF7) may be already useful for risk stratification and potentially useful for prognosis and treatment [30, 31]. A recent (not yet peer-reviewed) study that has appeared on medRxiv [52], did not find penetrating rare alleles associated with a severe disease phenotype in four different cohorts analyzed by whole-exome or whole-genome sequencing, thus questioning whether the data by Zhang et al. [31] have general validity. These discrepancies might be attributed at least in part to the heterogeneity of biobanks, to how phenotypic stratification is clinically assessed, and to how functional studies are conducted [31].

Identifying the role of rare variants is important in order to improve predictive testing, to unravel the pathogenetic mechanisms in different subgroups of SARS-CoV-2 positive subjects, and to develop personalized medicine for individual COVID-19 patients tailored to his or her genetic background. It is possible that, in a complex multifactorial and multigenic disease, such as COVID-19, several genetic and epigenetic factors are modulating the phenotypic manifestation, thus complicating the analysis of genotype-phenotype correlations. For example, it is known that non-coding RNAs 
Table 2 Genetic risk factors for severe COVID-19

\begin{tabular}{|c|c|c|c|}
\hline SARS-CoV-2 susceptibility gene variant or haplotype & $\begin{array}{l}\text { Risk estimated } \\
\text { [OR] }\end{array}$ & $\begin{array}{l}\text { Frequency } \\
\text { [MAF] }\end{array}$ & References \\
\hline $\begin{array}{l}\text { TLR3, UNC93B1, TICAM1, TBK1, IRF3, IRF7, IFNAR1, IFNAR2 (autosomal- } \\
\text { dominant model) }\end{array}$ & 9 & $<0.001$ & Zhang et al. [31] \\
\hline IRF7, IFNAR1 (autosomal-recessive model) & $>50$ & $<0.001$ & Zhang et al. [31] \\
\hline rs769208985—missense variant of FURIN & N.A. & $<0.001$ & Latini et al. [32] \\
\hline rs150892504-missense variant of ERAP2 & N.A. & 0.002 & Hu et al. [33] \\
\hline rs138763430—-missense variant of BRF2 & N.A. & 0.002 & Hu et al. [33] \\
\hline rs147149459-missense variant of ALOXE3 & N.A. & 0.002 & Hu et al. [33] \\
\hline rs117665206—missense variant of TMEM181 & N.A. & 0.006 & Hu et al. [33] \\
\hline rs114363287—missense variant of TMPRSS2 & N.A. & 0.006 & Latini et al. [32] \\
\hline HLA DRB*27:07 & N.A. & 0.02 & Novelli et al. [34] \\
\hline rs74956615-3'UTR variant of TYK2 & 1.6 & 0.03 & Pairo-Castineira et al. [35] \\
\hline rs73064425 - intronic variant of LZTFL1 & 2.1 & 0.08 & $\begin{array}{l}\text { Pairo-Castineira et al. [35], Ellinghaus } \\
\text { et al. [36] }\end{array}$ \\
\hline rs11385942-intronic variant of LZTFL1 & 1.8 & 0.07 & Ellinghaus et al [36] \\
\hline HLA DQB1*06:02 & N.A. & 0.08 & Novelli et al. [34] \\
\hline rs143334143-intronic variant of CCHCR1 & 1.9 & 0.09 & Pairo-Castineira et al. [35] \\
\hline HLA DRB1*15:01 & N.A. & 0.10 & Novelli et al. [34] \\
\hline rs6598045-5'UTR variant of IFITM3 & N.A. & 0.19 & Kim et al. [37] \\
\hline rs429358-missense variant of APOE & $2.3-2.4$ & 0.20 & Kuo et al. [38] \\
\hline rs9380142-3'UTR variant of HLA-G & 13 & 0.29 & Pairo-Castineira et al. [35] \\
\hline rs2109069-intronic variant of DPP9 & 1.4 & 0.33 & Pairo-Castineira et al. [35] \\
\hline rs75603675-missense variant of TMPRSS2 & N.A. & 0.36 & Latini et al. [32] \\
\hline rs12329760_missense variant of TMPRSS2 & 0.9 & 0.39 & Hou et al. [39] \\
\hline rs657152 - intronic variant of $A B O$ & 1.3 & 0.41 & Ellinghaus et al. [36] \\
\hline rs6020298-intronic variant of TMEM189-UBE2V1 & 1.2 & 0.58 & Wang et al. [40] \\
\hline rs10735079_-intronic variant of OAS1/3 & 1.3 & 0.64 & Pairo-Castineira et al. [35] \\
\hline rs2236757-intronic variant of IFNAR2 & 1.3 & 0.71 & Pairo-Castineira et al. [35] \\
\hline rs3131294-intronic variant of NOTCH4 & 1.5 & 0.9 & Pairo-Castineira et al. [35] \\
\hline HLA B*46:01 & 2.1 & N.A. & Lin et al. [41] \\
\hline HLA-E*0101/0103 & $2.1 / 2.7$ & N.A. & Vietzen et al. [42] \\
\hline$K L R C 2^{\text {del }}$ & $2.6 / 7.1$ & N.A. & Vietzen et al. [42] \\
\hline HLA B*54:01 & 5.4 & N.A. & Lin et al. [41] \\
\hline c.2129_2132del, p.Gln710Argfs*18_frameshift variant of TLR7 & N.A. & N.A. & van der Made et al. [43] \\
\hline c.2383G>T, p.Val795Phe—missense variant of TLR7 & N.A. & N.A. & van der Made et al. [43] \\
\hline rs140312271—missense variant of ACE2 & N.A. & N.A. & Novelli et al. [44] \\
\hline
\end{tabular}

MAF major allele frequency, N.A. not applicable, $O R$ odds ratio

(ncRNAs), and in particular microRNAs (miRNAs), are involved in the pathogenesis of SARS-CoV-2 infection and in host antiviral immune defense mechanisms [53]. Genes encoding miRNAs, like other genes, show interindividual genetic variability, and several studies have shown that genetic variants in miRNA genes can, in some cases, affect their expression, maturation, and even affinity for their target genes [54, 55]. Thus, the high clinical variability of COVID-19 might be influenced by polymorphisms in microRNA target sites (MTS) or in miRNA sequences [55]. Genetic and epigenetic differences in miRNA expression in cells targeted by the virus during entry could affect the effectiveness of antiviral responses and therefore disease severity. Interestingly, it has recently been shown that level of expression of genes encoding proteins involved in virus attachment and entry (e.g., ACE2, TMPRSS2) varies with age and may provide a biological rationale for variability in 
presentation of COVID-19 [56]. Recently, Blume et al. [57] identified a new short isoform of ACE2 expressed in the airway epithelium. Short ACE2 is upregulated in response to interferon stimulation and rhinovirus, but not SARS-CoV-2 infection. Its expression is regulated independently of the primary transcript, with putative promoter elements identified upstream of the transcriptional initiation site of the short ACE2 transcript. The characterization of the functional elements of the ACE2 promoter and above all the factors involved in its regulation will help to understand better the mechanisms of pathology caused by SARS-CoV-2.

Newly the CHGE Consortium (Covid Human Genetic Effort, https://www.covidhge.com/about) initiated a study to enroll individuals (referred to as "resistant") who were not infected with SARS-CoV-2 despite repeated exposure (e.g., care-givers or familiars of a patient with severe pneumonia), as evidenced by the absence of the disease and virus specific antibody titers in several tests. It is conceivable that these subjects carry monogenic variations that make them naturally resistant to virus entry, as previously shown for the DARC gene and Plasmodium vivax, CCR5 and HIV, and FUT2 and Norovirus [58-60]. Currently, there are no publications on this "resistant cluster," but recently, Zeberg and Pääbo [61] have identified an haplotype on chromosome 12, which is associated with a $\sim 22 \%$ reduction in relative risk of becoming severely ill with COVID-19 when infected by SARS-CoV-2. Interestingly, this haplotype is inherited from Neanderthals and it is present at substantial frequencies in all regions of the world outside Africa. The genomic region where this haplotype occurs encodes proteins that are important during infections with RNA viruses.

\section{COVID-19 in Africa and in Latin America}

Considering the multifactorial complexity of this disease, its rapid epidemic spread, and its fast evolving causative agent, COVID-19 is ravaging emerging countries, and its impacts in low-resource areas deserves our attention and action. We focus here on two regions of particular interest: Africa and Latin America.

On January 1, 2021, J. M. Maeda and J. N. Nkengasong published a paper on "The puzzle of the COVID-19 pandemic in Africa" [62]. The figure in the paper depicts the two COVID-19 "waves" seen in Europe are much less evident in Africa: rather, there has been a peak in July, 2020, followed by a gradual decrease and in turn by a gradual increase that is still on-going. The real "puzzle" is that a previous report (issued on March 26, 2020, by the WHO Collaborating Centre for Infectious Disease Modeling; MRC Centre for Global Infectious Disease) had predicted some 70 million cases and some 3 million deaths in
Africa; in contrast, by November 22, 2020, the official figures were 2,070,953 cases and 49,728 deaths. The authors (who are at the Africa Centers for Disease Control and Prevention-the African CDC-in Addis Ababa, Ethiopia) mention "challenges with testing" as one possible reason for this striking discrepancy. This notion is also supported by a compilation from Nigeria [63]; according to official data, three-quarters of African COVID-19 cases are in South Africa and Egypt. An extreme case is that of Tanzania, where the COVID-19 epidemic is officially finished, and the last recorded case was on May 19, 2020. We think limited testing is a major reason for the paucity of cases in Africa.

Be that as it may, at least three factors of biological and epidemiological interest may have contributed to reducing the impact of the pandemic in Africa. First, in tropical Africa, sun exposure and UV radiation may inactivate an RNA virus rather more quickly. However, this hypothesis is not confirmed in other countries such as northern Brazil and other regions of the tropics where COVID-19 is found. Furthermore, the mode of transmission that occurs through droplets and aerosols does not fit this hypothesis. Second, the age distribution of the population is much younger. Third, a significant fraction of people (perhaps up to 30\%) [64] may have antibodies against other corona viruses that cross-react with SARS-CoV2 (even though only $2-8 \%$ have specific anti-SARSCoV2 antibodies suggesting there may be, like in Europe, a large number of asymptomatic infections) [65]. Latin America has also been ravaged by COVID-19 and may be the world's worst affected region [66]. Vaccinations against the virus are seen as the way forward and have begun (https://www.as-coa.org/ articles/timeline-latin-americas-race-covid-19-vaccine) [67]. We must support a path to a world that defeats COVID-19 in all parts of the world. In fact international efforts by the Global Vaccine Alliance (GAVI), Coalition for Epidemic Preparedness Innovations (CEPI), Gates Foundations, WHO, etc. (https:// www.weforum.org/agenda/2020/06/vaccines immunization-poor-countries-coronavirus-covid-gavi) [68] are thankfully ramping up.

\section{New technologies accelerated into clinical practice}

The pandemic has produced an unprecedented shift in the direction of basic and clinical research. We think it is remarkable that so many highly qualified research laboratories have been eager or willing to bring their experience in other areas to bear on this impelling worldwide problem, and we think it is commendable that they have had the courage to literally 
re-purpose their work. There has been also a deluge of publications: at March 30, 2021, the search item COVID-19 in PubMed yields 118,065 papers; by the time this paper is published, there will be several thousands more publications. At the same time, new technologies for disease treatment and prevention are also being developed at unprecedented speed. In general, it takes a long time for advances to reach consumers, especially in the areas of biotechnology and health. However, the pandemic has led to a dramatic acceleration, including in the development of COVID19 vaccines (Table 3) [69].

\section{Monoclonal antibodies}

Although there are currently numerous studies to identify antivirals for SARS-CoV-2, the only compounds with therapeutic efficacy already in use are monoclonal antibodies (mAbs). mAbs are directed against the binding site of the SARS-CoV-2 spike protein receptor and they are able to block virus entry into human cells. mAbs

Table 3 Overview of the worldwide approved different types of COVID-19 vaccines

\begin{tabular}{|c|c|c|c|c|c|c|c|}
\hline Vaccine & $\begin{array}{l}\text { Product } \\
\text { name }\end{array}$ & $\begin{array}{l}\text { Vaccine } \\
\text { type }\end{array}$ & $\begin{array}{l}\text { Phase } \\
\text { III } \\
\text { efficacy }\end{array}$ & Doses & Storage & $\begin{array}{l}\text { Prize } \\
\text { per dose }\end{array}$ & Distribution \\
\hline BioNTech/Pfizer & BNT162b2 & mRNA & $95 \%$ & $\begin{array}{l}2 \text { doses }(0.3 \\
\mathrm{mL})[21 \\
\text { days apart] }\end{array}$ & $\begin{array}{l}-80 \text { and }-60{ }^{\circ} \mathrm{C} \\
(-112 \text { and }-76 \\
\left.{ }^{\circ} \mathrm{F}\right) \text { for } 6 \\
\text { months } \\
+2 \text { and }+8{ }^{\circ} \mathrm{C} \\
(+36 \text { and }+46 \\
\left.{ }^{\circ} \mathrm{F}\right) \text { for } 5 \text { days }\end{array}$ & $19.5 \$$ & $\begin{array}{l}\text { USA, EU, UK, Argentina, Australia, Bahrain, } \\
\text { Canada, Chile, Costa Rica, Ecuador, Hong Kong, } \\
\text { Iraq, Israel, Jordan, Kuwait, Malaysia, Mexico, } \\
\text { Oman, Panama, Philippines, Qatar, Saudi Arabia, } \\
\text { Singapore, South Korea, United Arab Emirates } \\
\text { COVAX (COVID-19 Vaccines Global Access) }\end{array}$ \\
\hline Moderna & mRNA-1273 & mRNA & $94.1 \%$ & $\begin{array}{l}2 \text { doses }(0.5 \\
\mathrm{mL})[28 \\
\text { days apart] }\end{array}$ & $\begin{array}{l}-20{ }^{\circ} \mathrm{C}\left(-4{ }^{\circ} \mathrm{F}\right) \\
\text { for } 4 \text { months } \\
+2 \text { and }+8{ }^{\circ} \mathrm{C} \\
(+36 \text { and }+46 \\
\left.{ }^{\circ} \mathrm{F}\right) \text { for } 30 \text { days }\end{array}$ & $32-37 \$$ & $\begin{array}{l}\text { USA, EU, UK, Canada, Greenland, Iceland, Israel, } \\
\text { Saudi Arabia, Singapore, Vietnam } \\
\text { COVAX (COVID-19 Vaccines Global Access) }\end{array}$ \\
\hline $\begin{array}{l}\text { Oxford/ } \\
\text { AstraZeneca }\end{array}$ & $\begin{array}{l}\text { ChAdOx1 } \\
\text { AZD1222/ } \\
\text { Vaxzevria }\end{array}$ & Viral vector & $81.3 \%$ & $\begin{array}{l}2 \text { doses }(0.5 \\
\mathrm{mL})[10-12 \\
\text { weeks } \\
\text { apart] }\end{array}$ & $\begin{array}{l}+2 \text { and }+8{ }^{\circ} \mathrm{C} \\
(+36 \text { and }+46 \\
\left.{ }^{\circ} \mathrm{F}\right)\end{array}$ & $1.5-4 \$$ & $\begin{array}{l}\text { USA, EU, UK, Australia, Bangladesh, Brazil, } \\
\text { Canada, Greenland, India, Mexico, Nepal, } \\
\text { Pakistan, Philippines, Sri Lanka, Taiwan, Vietnam } \\
\text { COVAX (COVID-19 Vaccines Global Access) }\end{array}$ \\
\hline $\begin{array}{l}\text { Gamaleya } \\
\text { (Sputnik V) }\end{array}$ & $\begin{array}{l}\text { Sputnik V } \\
\text { Gam-Covid- } \\
\text { Vac }\end{array}$ & Viral vector & $91.6 \%$ & $\begin{array}{l}2 \text { doses }(0.5 \\
\mathrm{mL}) \\
{[28 \text { days }} \\
\text { apart }]\end{array}$ & $\begin{array}{l}-18{ }^{\circ} \mathrm{C}\left(0{ }^{\circ} \mathrm{F}\right) \\
\text { for } 24 \text { months } \\
+2 \text { and }+8{ }^{\circ} \mathrm{C} \\
(+36 \text { and }+46 \\
\left.{ }^{\circ} \mathrm{F}\right) \text { for } 3 \\
\text { months }\end{array}$ & $<10 \$$ & $\begin{array}{l}\text { Russia, India, Brazil, China, South Korea, Hungary, } \\
\text { Argentina }\end{array}$ \\
\hline Johnson\&Johnson & $\begin{array}{l}\text { JNJ- } \\
78436735 \\
\text { Ad26.COV2.S }\end{array}$ & Viral vector & $72 \%$ & 1 dose & $\begin{array}{l}-18{ }^{\circ} \mathrm{C}\left(0{ }^{\circ} \mathrm{F}\right) \\
\text { for } 24 \text { months } \\
+2 \text { and }+8{ }^{\circ} \mathrm{C} \\
(+36 \text { and }+46 \\
{ }^{\circ} \text { F) for } 3 \\
\text { months }\end{array}$ & $10 \$$ & $\begin{array}{l}\text { USA, EU, Greenland, Canada } \\
\text { COVAX (COVID-19 Vaccines Global Access) }\end{array}$ \\
\hline Novavax & $\begin{array}{l}\text { NVX- } \\
\text { CoV2373 }\end{array}$ & $\begin{array}{l}\text { Virus-like } \\
\text { particle }\end{array}$ & $89 \%$ & $\begin{array}{l}2 \text { doses }[21 \\
\text { days apart] }\end{array}$ & $\begin{array}{l}-18{ }^{\circ} \mathrm{C}\left(0{ }^{\circ} \mathrm{F}\right) \\
\text { for } 24 \text { months } \\
+2 \text { and }+8{ }^{\circ} \mathrm{C} \\
(+36 \text { and }+46 \\
\left.{ }^{\circ} \mathrm{F}\right) \text { for } 3 \\
\text { months }\end{array}$ & $16 \$$ & USA, Canada \\
\hline Sinopharm & BBIBP-CorV & $\begin{array}{l}\text { Inactivated } \\
\text { virus }\end{array}$ & $78 \%$ & $\begin{array}{l}2 \text { doses [3 } \\
\text { weeks } \\
\text { apart] }\end{array}$ & $\begin{array}{l}+2 \text { and }+8{ }^{\circ} \mathrm{C} \\
(+36 \text { and } \\
\left.+46^{\circ} \mathrm{F}\right) \\
\text { Three years in } \\
\text { storage }\end{array}$ & $<77 \$$ & $\begin{array}{l}\text { China, United Arab Emirates, Argentina, Bahrain, } \\
\text { Egypt, Marocco, Pakistan, Perù }\end{array}$ \\
\hline SinoVac & CoronaVac & $\begin{array}{l}\text { Inactivated } \\
\text { virus }\end{array}$ & $50 \%$ & $\begin{array}{l}2 \text { doses }[3 \\
\text { weeks } \\
\text { apart] }\end{array}$ & $\begin{array}{l}2-8{ }^{\circ} \mathrm{C}(36-46 \\
\left.{ }^{\circ} \mathrm{F}\right) \\
\text { Three years in } \\
\text { storage }\end{array}$ & $14 \$$ & China, Brazil, Turkey, Chile, Indonesia, Philippines \\
\hline $\begin{array}{l}\text { Covaxin (Bharat } \\
\text { Biontech) }\end{array}$ & BBV152 & $\begin{array}{l}\text { Inactivated } \\
\text { virus }\end{array}$ & $81 \%$ & $\begin{array}{l}2 \text { doses }[21 \\
\text { days apart] }\end{array}$ & $\begin{array}{l}2-8{ }^{\circ} \mathrm{C}(36-46 \\
\left.{ }^{\circ} \mathrm{F}\right) \\
\text { Three years in } \\
\text { storage }\end{array}$ & $1 \$$ & India, Iran, Mauritius, Nepal, Zimbabwe \\
\hline
\end{tabular}


have this name because they are produced by one type of immune cells (plasma cells) that are the progeny of a single parent cell [70]. mAbs, are laboratory-produced macromolecules engineered to bind to antigens of selected targets (e.g., cancer cells, microorganisms, viruses) [71]. The efficacy of mAbs has been successfully tested in other coronavirus infections (SARS-CoV) [72-74] and MERS [75]. During the past 12 months, several SARS$\mathrm{CoV}-2$ neutralizing mAbs have been isolated and characterized in several clinical studies (NCT04452318, NCT04497987). Some of these, such as bamlanivimab, casirivimab, and imdevimab, have been approved for emergency use in the treatment of mildly ill subjects. mAbs regarded as good candidates for clinical use have been derived by cloning $\mathrm{B}$ cells from patients who have recovered from COVID-19, or from other natural sources [76-82]. Bamlanivimab has been associated with a decrease in viral load and the frequency of hospitalizations or emergency department visits in outpatients with COVID-19 [83]; however, when it was co-administered with Remdesivir, it did not demonstrate efficacy among hospitalized patients who had COVID-19 without endorgan failure [84]. In a double-blind, phase I-III trial involving non-hospitalized COVID-19 patients, Weinreich et al. [85] investigated two fully neutralizing mAbs used in combination (casirivimab/imdevimab or REGNCOV2), in the aim to reduce the risk that treatmentresistant virus variants may emerge. REGN-COV2, developed by Regeneron Pharmaceuticals (USA), reduced viral load, with a greater effect in patients whose immune response to the virus had not yet been initiated, or who had a high viral replication at baseline. Very recent and unpublished data show that treatment with bamlanivimab (LY-CoV555) and etesevimab (LY-CoV016) together reduced the risk of hospitalization and death from COVID-19 by 70\% (https://investor.lilly.com/newsreleases/news-release-details/new-data-show-treatmentlillys-neutralizing-antibodies) [86]. Recently, EMA (European Medicines Agency) has completed review on the use of an additional mAb, regdanvimab (also known as CT-P59) to treat COVID-19 patients and concluded that regdanvimab can be used for the treatment of confirmed COVID-19 in adult patients who do not require supplemental oxygen therapy and who are at high risk of progressing to severe outcome (https://www.ema.europa.eu/ en/news/ema-review-regdanvimab-covid-19-supportnational-decisions-early-use) [87].

mAbs may be also useful for the prophylaxis of COVID-19 in persons who are at high-risk (health workers and first responders, pregnant women, ringvaccination-type response to disease outbreak). By applying an innovative strategy, Miersch et al. $[88,89]$ have isolated high affinity synthetic mAbs from a phage library and thus developed a dynamic and rapid technological platform; this approach has the potential to identify in a short time mAbs against new virus variants. Synthetic engineering technologies may prove superior to natural cloning methods, as they offer exquisite control over the design of mAbs, that can prove more efficient. Similarly, Rappazzo et al. [90] identified rare broadly neutralizing antibodies (bnAbs) which can be engineered for improve neutralization potency and protection in vivo. Synthetic methods have the added advantage that they do not depend on natural repertoires, i.e., they are not limited by the need of accessing infected patients as a source of therapeutic agents. Andreano et al. [91] have isolated and characterized extremely potent neutralizing mAbs, suitable for prophylactic and therapeutic interventions of wild-type SARS$\mathrm{CoV}-2$ as well as emerging variants. Remarkably, an international research consortium recently developed a bispecific monoclonal antibody targeting two different SARS-CoV-2 sites, thereby preventing the virus from mutating to resist therapy. A single injection of the bispecific antibody provided protection against disease in mice. The antibody effectively reduced the viral load in the lungs and mitigated the typical COVID-19 inflammation [92].

\section{mRNA vaccines}

Vaccines against SARS-CoV-2 infection were made in less than a year (Table 3). This research has undoubtedly been a great success of modern technology and public and private investments that have allowed to accelerate many of the processes required to develop a vaccine. But, of course, mRNA vaccines represent an epochal scientific and technical breakthrough.

mRNA was discovered in 1961 by Brenner et al. [93] and its ability to form drugs has been described already in 1989 [94, 95]. Since then, dozens of studies on the subject have been published, including a study on a vaccine against the MERS-CoV, which allowed the accelerated development of the SARS-CoV-2 vaccine [96]. This technology enables the synthetic production of the mRNA encoding any protein. mRNA vaccines have advantages over DNA vaccines. In general, lower doses are required to induce an immune response. Synthetic mRNA does not integrate into the cell's genome, and no transcriptional step is involved, as the mRNA is directly translated, and then it undergoes degradation [97]. The vaccine activates both humoral immune system and cellular immune response, similar to live virus attenuated vaccine [98-100].

The safety data in adults on mRNA vaccines against COVID-19 have been reassuring. The most common side effects in adults are only local, within 7 days of receiving the first inoculation, and more common after the second dose [101, 102]. The side effects are mild-to-moderate; no 
severe-grade local side effects were reported $[98,103]$. Systemic signs (fever of $38{ }^{\circ} \mathrm{C}$ ) were reported in $75 \%$ of vaccine recipients. Subjects over the age of 65 suffered less systemic symptoms, but reported fatigue and headaches. During the rollout, some severe allergic reactions were also observed, but they were rare [104].

RNA-based vaccines efficacy, safety, and the potential for rapid, inexpensive, and scalable production makes them a powerful advantageous option to combat COVID-19, including probably new variants [105-110]. Widge et al. [111] have reported immunogenicity data 119 days after the first dose of vaccine (i.e., 90 days after the second dose) in 34 healthy adult participants who received two injections of $100 \mu \mathrm{g}$ each. They provided further evidence that mRNA-1273, developed by National Institute of Allergy and Infectious Diseases (NIAID), the Biomedical Advanced Research and Development Authority (BARDA), and Moderna (ModeRNA Therapeutics, USA) have the potential to provide a durable humoral immunity, although for how long is of course not yet known.

Recently, a CDC study of about 4000 healthcare workers and workers belonging to essential categories were tested weekly for coronavirus after administration of the mRNA vaccine. The analyses found that people who had completed the vaccination course had a $90 \%$ reduced chance of becoming infected. Furthermore, the study showed that already from the first dose, the percentage after 14 days from the first injection was already close to $80 \%$. Results clearly indicate the vaccine's ability to interrupt viral transmission [112].

mRNA-based drugs are a promising novel platform that might be useful for the development of vaccines against emerging pandemic infectious diseases [113]. Furthermore, unconventional tools such as Cas13acrRNA complex, an RNA-activated RNase, are being explored as novel therapeutics against SARS-CoV-2 infection, displaying promising results in reducing viral replication and symptoms in animal models [114]. RNA in human cells is susceptible to editing, and the RNA genome of SARS-CoV-2 is not an exemption. From a comprehensive sequence analysis of Coronaviridae, nucleotide changes have been identified that may be signatures of RNA editing by both ADAR deaminases and APOBEC deaminases. It has been suggested that this process may contribute to shaping the fate of both virus and patient [115].

\section{Conclusions}

We are heartened by the progress in therapeutics and preventive strategies for COVID-19. Having achieved within less than 1 year from the start of the pandemic not only the development of a vaccine but also of several vaccines; having conducted the necessary clinical trials; having obtained approval from multiple regulatory agencies around the world; having actually already carried out mass vaccinations at least in some countries, is nothing short of spectacular [68]. While we can certainly not relent on the standard preventive measures (rigorous social distancing, frequent and thorough handwashing, avoiding poorly ventilated spaces, wearing of face masks as warranted), we are confident that the vaccines currently available and those in the pipeline will help defeat COVID-19 and allow a return to normality in due course $[116,117]$. Improved therapies, such as mAbs, will also be useful in treating the disease. Understanding the virus entry and egress mechanisms could also open the door to promising therapeutic perspectives [118, 119]. Molecular testing and genomics will play a critical role in the detection of newly emerging variants.

Furthermore, we are mindful of our fellow humans in other countries, particularly in emerging economies. For many years, the Global Fund has provided funding for those affected by HIV; it has been a generous gesture, initially fueled by concerns that from a reservoir in Africa transmission elsewhere could take place. If HIV has been an epidemic, SARS-CoV-2 has sparked a pandemic, and it will be in everybody's interest that it is controlled on a global scale because, as stated at the beginning of this paper, otherwise it will continue to affect the world. We are aware that WHO has launched the COVAX (COVID-19 Vaccines Global Access) scheme, and that the GAVI, backed by the Bill \& Melinda Gates Foundation, the WHO, the World Bank, UNICEF, and others, has pledged $\$ 8.8$ billion to reduce vaccine costs for poor countries. One possibility is that a good part of these funds will be absorbed by vaccinating persons from poor countries and provide immunization certificates to those who travel to richer countries, so that the latter will be protected. But we call on international organizations to set aside this potential narrow-sighted approach: and make instead vaccines available to all nations on a wide scale. We look forward to the WHO leading rigorously and expeditiously, lest their effectiveness is brought into question more than it has been hitherto. It is legitimate to hope that the lessons learned with COVID-19 will help in the future, not only in being more prepared for other similar emergencies but also in acting as one, for we have only one planet and only one humankind.

\footnotetext{
Abbreviations

ARDS: Acute respiratory distress syndrome; ASEAN: Organization of Southeast Asian States; AU: African Union; BARDA: Biomedical Advanced Research and Development Authority; CDC: Centers for Disease Control; CEPI: Coalition for Epidemic Preparedness Innovations; CHGE: Covid Human Genetic Effort; COPD: Chronic obstructive pulmonary disease; COVAX: COVID-19 Vaccines Global Access; COVID-19: Coronavirus disease 2019; CTAP: Coronavirus Treatment Acceleration Program; EMA: European Medicine Agency; EU: European Union; EUA: Emergency Use Authorization; FAO: Food and Agriculture Organization; FDA: Food and Drug Administration; GAVI: Global Vaccine Alliance; GWAS: Genome Wide Association Studies; IFR: Infection
} 
fatality rate; mAbs: Monoclonal antibodies; miRNA: micro RNA; MERS: Middle East respiratory syndrome; NIAID: National Institute of Allergy and Infectious Diseases; OAS: Organization of American States; ORF: Open reading frame; OSAS: Obstructive sleep apnea syndrome; SARS-CoV-2: Severe acute respiratory syndrome coronavirus 2; UN: United Nations; WHO: World Health Organization

\section{Supplementary Information}

The online version contains supplementary material available at https://doi. org/10.1186/s40246-021-00326-3.

Additional file 1: Table S1. List of genomes used in the analysis. We gratefully acknowledge the following Authors from the Originating laboratories responsible for obtaining the specimens, as well as the Submitting laboratories where the genome data were generated and shared via GISAID, on which this research is based.

\section{Acknowledgements}

We are particularly grateful for the assistance given by Dr. Francesca Pisanu for her continuous help with the editing and organization of the manuscript.

\section{Authors' contributions}

G.N. and J.K.V.R. conceived the paper, performed the systematic review, wrote and edited the manuscript. R.M.S. wrote mRNA vaccines paragraph. J.K.V.R. is also responsible for the sections on acceleration of technologies and politics along with some revisions. V.L.C. conceived and edited Table 2, Table 3, and revised the paper. A.F.B. generated Fig. 1. M.B., V.V., A.F.B., L.L., and N.D.G. performed review and revision of the paper. All authors read and approved the final version of the manuscript.

\section{Funding}

This study was also supported in part by a grant of Regione Lazio (Italy, Progetti di Gruppi di Ricerca 2020 A0375-2020-36663 GecoBiomark) and Rome Foundation (Italy, Prot 317A/I) to GN and NIH N. AA028432 to V.V.

\section{Availability of data and materials}

Data sharing is not applicable to this article as no datasets were generated or analyzed during the current study.

\section{Declarations}

Ethics approval and consent to participate

Not applicable.

\section{Consent for publication}

Not applicable.

\section{Competing interests}

The authors declare that they have no competing interests.

\section{Author details}

${ }^{1}$ Department of Biomedicine and Prevention, "Tor Vergata" University of Rome, 00133 Rome, Italy. ${ }^{2}$ IRCCS Neuromed, Pozzilli, IS, Italy. ${ }^{3}$ Department of Pharmacology, School of Medicine, University of Nevada, Reno, NV 89557, USA. ${ }^{4}$ Department of Biology, Tor Vergata University of Rome, 00133 Rome, Italy. ${ }^{5}$ Pediatric Hemato-Oncology, Sheba Medical Center, Tel Hashomer, Israel. 'Department of Epidemiology of Microbial Diseases, Yale School of Public Health, New Haven, CT 06510, USA. D. Department of Environmental Health Sciences, Yale School of Public Health, New Haven, CT 06510, USA ${ }^{8}$ Haematology, Muhimbili University of Health and Allied Sciences, Dar-es Salaam, Tanzania. ${ }^{9}$ Australian Institute of Tropical Health and Medicine, James Cook University, Smithfield, Queensland 4878, Australia.
Received: 8 February 2021 Accepted: 15 April 2021

Published online: 10 May 2021

\section{References}

1. Green MS. Did the hesitancy in declaring COVID-19 a pandemic reflect a need to redefine the term? Lancet. 2020;395(10229):1034-5. https://doi. org/10.1016/S0140-6736(20)30630-9.

2. U.S. Food \& Drug Administration (2021). Fda.gov "fda.gov". Retrieved 31/03, 2021, from https://www.fda.gov/drugs/coronavirus-covid-19-drugs/corona virus-treatment-acceleration-program-ctap.

3. Chaib, F. (2020). "Independent evaluation of global COVID-19 response announced". Retrieved 27/01, 2021, from https://www.who.int/news/item/ 09-07-2020-independent-evaluation-of-global-covid-19-response-a nnounced.

4. Kupferschmidt K, Vogel G (2021). Sciencemag.org "sciencemag.org". Retrieved 31/03, 2021, from https://www.sciencemag.org/news/2021/03/ compromise-who-report-resolves-little-pandemic-s-origins-details-probe-snext-steps.

5. Robson F, Khan KS, Le TK, Paris C, Demirbag S, Barfuss P, et al. Coronavirus RNA proofreading: molecular basis and therapeutic targeting. Mol Cell. 2020;79(5):710-27Erratum in: Mol Cell. 2020 Dec 17;80(6):1136-1138. https:// doi.org/10.1016/j.molcel.2020.11.048.

6. Duffy S, Shackelton LA, Holmes EC. Rates of evolutionary change in viruses: patterns and determinants. Nat Rev Genet. 2008;9(4):267-76. https://doi. org/10.1038/nrg2323.

7. Daugherty MD, Malik HS. Rules of engagement: molecular insights from host-virus arms races. Annu Rev Genet. 2012;46(1):677-700. https://doi.org/1 0.1146/annurev-genet-110711-155522.

8. Mandary MB, Masomian M, Poh CL. Impact of RNA virus evolution on quasispecies formation and virulence. Int J Mol Sci. 2019;20(18):4657. https:// doi.org/10.3390/ijms20184657.

9. Stern A, Bianco S, Yeh MT, Wright C, Butcher K, Tang C, et al. Costs and benefits of mutational robustness in RNA viruses. Cell Rep. 2014;8(4):102636. https://doi.org/10.1016/j.celrep.2014.07.011.

10. GISAID (2020). "Global initiative on sharing avian flu data". Retrieved 31/03, 2021, from https://www.gisaid.org/.

11. Nextstrain (2021). "Real-time tracking of pathogen evolution". Retrieved 31/ 03, 2021, from https://nextstrain.org/ncov/global.

12. Hadfield J, Megill C, Bell SM, Huddleston J, Potter B, Callender C, et al. Nextstrain: real-time tracking of pathogen evolution. Bioinformatics. 2018; 34(23):4121-3. https://doi.org/10.1093/bioinformatics/bty407.

13. Huang SW, Miller SO, Yen CH, Wang SF. Impact of genetic variability in ACE2 expression on the evolutionary dynamics of SARS-CoV-2 spike D614G mutation. Genes (Basel). 2020;12(1):E16.

14. Wise J. Covid-19: new coronavirus variant is identified in UK. BMJ. 2020;371: m4857.

15. Plante JA, Liu Y, Liu J, Xia H, Johnson BA, Lokugamage KG, et al. Spike mutation D614G alters SARS-CoV-2 fitness. Nature. 2021; 592(7852):116-21. https://doi.org/10.1038/s41586-020-2895-3.

16. Kemp SA, Datir RP, Collier DA, Ferreira IATM, Carabelli A, Harvey W, Robertson DL, Gupta RK. Recurrent emergence and transmission of a SARSCoV-2 Spike deletion $\Delta H 69 / \Delta V 70$. bioRxiv. 2020. https://doi.org/10.1101/202 0.12 .14 .422555 .

17. Tegally H, Wilkinson E, Giovanetti M, Iranzadeh A, Fonseca V, Giandhari J, et al. Emergence and rapid spread of a new severe acute respiratory syndrome-related coronavirus 2 (SARS-CoV-2) lineage with multiple spike mutations in South Africa. medRxiv. 2020. https://doi.org/10.1101/202 0.12 .21 .20248640 .

18. Da Silva FR Jr, Benites FJ, Lamarca AP, de Almeida LGP, Hansen AW, Gularte JS, et al. Pervasive transmission of E484K and emergence of VUI-NPI3L with evidence of SARS-CoV-2 co-infection events by two lineages in Rio Grande do Sul, Brasil.Virus Res. 2021;296:198345.https://doi.org/10.1016/j.virusres.2 021.198345

19. Deng X, Garcia-Knight MA, Khalid MM, Servellita V, Wang C, Morris MK, et al. Transmission, infectivity, and antibody neutralization of an emerging SARSCoV-2 variant in California carrying a L452R spike protein mutation. medRxiv. 2021. https://doi.org/10.1101/2021.03.07.21252647.

20. Abdool Karim SS, de Oliveira T. New SARS-CoV-2 variants - clinical, public health, and vaccine implications. N Engl J Med. 2021. https://doi.org/10.1 056/NEJMc2100362 
21. Tarke A, Sidney J, Methot N, Zhang Y, Dan JM, Goodwin B, et al. Negligible impact of SARS-CoV-2 variants on $\mathrm{CD}^{+}$and $\mathrm{CD}^{+} \mathrm{T}$ cell reactivity in COVID19 exposed donors and vaccinees. bioRxiv. 2021. https://doi.org/10.1101/2 021.02.27.433180.

22. Challen R, Brooks-Pollock E, Read JM, Dyson L, Tsaneva-Atanasova K, Danon L. Risk of mortality in patients infected with SARS-CoV-2 variant of concern 202012/1: matched cohort study. BMJ. 2021. https://doi.org/10.1136/bmj. $\mathrm{n} 579$.

23. Alpert T, Lasek-Nesselquist E, Brito AF, Valesano AL, Rothman J, MacKay MJ, et al. Early introductions and community transmission of SARS-CoV-2 variant B.1.1.7 in the United States. medRxiv.2021.02.10.21251540.

24. Cyranoski D. Alarming COVID variants show vital role of genomic surveillance. Nature. 2021;589(7842):337-8. https://doi.org/10.1038/d41586021-00065-4.

25. Levin AT, Hanage WP, Owusu-Boaitey N, Cochran KB, Walsh SP, MeyerowitzKatz G. Assessing the age specificity of infection fatality rates for COVID-19: systematic review, meta-analysis, and public policy implications. Eur J Epidemiol. 2020;35(12):1123-38. https://doi.org/10.1007/s10654-020-00698-1.

26. Huang C, Wang Y, Li X, Ren L, Zhao J, Hu Y, et al. Clinical features of patients infected with 2019 novel coronavirus in Wuhan, China. Lancet. 2020;395(10223):497-506. https://doi.org/10.1016/S0140-6736(20)30183-5.

27. Novelli L, Motta F, De Santis M, Ansari AA, Gershwin ME, Selmi C. The JANUS of chronic inflammatory and autoimmune diseases onset during COVID-19 - a systematic review of the literature. J Autoimmun. 2020;117: 102592.

28. Guler SA, Ebner L, Beigelman C, Bridevaux PO, Brutsche M, Clarenbach C, et al. Pulmonary function and radiological features four months after COVID-19: first results from the national prospective observational Swiss COVID-19 lung study. Eur Respir J. 2021:2003690. https://doi.org/10.1183/13 993003.03690-2020.

29. Di Maria E, Latini A, Borgiani P, Novelli G. Genetic variants of the human host influencing the coronavirus-associated phenotypes (SARS, MERS and COVID-19): rapid systematic review and field synopsis. Hum Genomics. 2020; 14(1):30. https://doi.org/10.1186/s40246-020-00280-6.

30. Zhang Q, Bastard P, Bolze A, Jouanguy E, Zhang SY, Cobat A, et al. Lifethreatening COVID-19: defective interferons unleash excessive inflammation. Med. 2020;1(1):14-20.

31. Zhang Q, Bastard P, Liu Z, Le Pen J, Moncada-Velez M, Chen J, et al. Inborn errors of type I IFN immunity in patients with life-threatening COVID-19. Science. 2020;370(6515):eabd4570. https://doi.org/10.1126/science.abd45702 020:eabd4570

32. Latini A, Agolini E, Novelli A, Borgiani P, Giannini R, Gravina P, et al. COVID19 and genetic variants of protein involved in the SARS-CoV-2 entry into the host cells. Genes (Basel). 2020;11(9):1010. https://doi.org/10.3390/ genes 11091010 .

33. Hu J, Li C, Wang S, Li T, Zhang H. Genetic variants are identified to increase risk of COVID-19 related mortality from UK Biobank data. medRxiv. 2020.11. 05.20226761 .

34. Novelli A, Andreani M, Biancolella M, Liberatoscioli L, Passarelli C, Colona $\mathrm{VL}$, et al. HLA allele frequencies and susceptibility to COVID-19 in a group of 99 Italian patients. HLA. 2020;96(5):610-4. https://doi.org/1 $0.1111 / \tan .14047$

35. Pairo-Castineira E, Clohisey S, Klaric L, Bretherick AD, Rawlik K, Pasko D, et al. Genetic mechanisms of critical illness in Covid-19. Nature. 2020.

36. Severe Covid-19 GWAS Group, Ellinghaus D, Degenhardt F, Bujanda L, Buti M, Albillos A, et al. Genomewide association study of severe Covid-19 with respiratory failure. N Engl J Med. 2020;383(16):1522-34. https://doi.org/10.1 056/NEJMoa2020283.

37. Kim $\mathrm{YC}$, Jeong $\mathrm{BH}$. Strong correlation between the case fatality rate of COVID-19 and the rs6598045 single nucleotide polymorphism (SNP) of the interferon-induced transmembrane protein 3 (IFITM3) gene at the population-level. Genes (Basel). 2020;12(1):42. https://doi.org/10.3390/ genes12010042.

38. Kuo CL, Pilling LC, Atkins JL, Masoli JAH, Delgado J, Kuchel GA, et al. APOE e4 genotype predicts severe COVID-19 in the UK biobank community cohort. J Gerontol A Biol Sci Med Sci. 2020;75(11):2231-2. https://doi.org/1 $0.1093 /$ gerona/glaa131

39. Hou Y, Zhao J, Martin W, Kallianpur A, Chung MK, Jehi L, et al. New insights into genetic susceptibility of COVID-19: an ACE2 and TMPRSS2 polymorphism analysis. BMC Med. 2020;18(1):216. https://doi.org/10.1186/ s12916-020-01673-z.
40. Wang F, Huang S, Gao R, Zhou Y, Lai C, Li Z, et al. Initial whole-genome sequencing and analysis of the host genetic contribution to COVID-19 severity and susceptibility. Cell Discov. 2020;6(1):83. https://doi.org/10.1038/ s41421-020-00231-4.

41. Lin M, Tseng HK, Trejaut JA, Lee HL, Loo JH, Chu CC, et al. Association of HLA class I with severe acute respiratory syndrome coronavirus infection. BMC Med Genet. 2003;4(1):9. https://doi.org/10.1186/1471-2350-4-9.

42. Vietzen H, Zoufaly A, Traugott M, Aberle J, Aberle SW, Puchhammer-Stöckl E. Deletion of the NKG2C receptor encoding KLRC2 gene and HLA-E variants are risk factors for severe COVID-19. Genet Med. 2021:1-5.

43. van der Made Cl, Simons A, Schuurs-Hoeijmakers J, van den Heuvel G, Mantere T, Kersten $\mathrm{S}$, et al. Presence of genetic variants among young men with severe COVID-19. JAMA. 2020;324(7):1-11. https://doi.org/10.1001/ja ma.2020.13719.

44. Novelli A, Biancolella M, Borgiani P, Cocciadiferro D, Colona VL, D'Apice MR, et al. Analysis of ACE2 genetic variants in 131 Italian SARS-CoV-2-positive patients. Hum Genomics. 2020;14(1):29. https://doi.org/10.1186/s40246-02000279-z.

45. Novelli G, Biancolella M, Mehrian-Shai R, Erickson C, Godri Pollitt KJ, Vasiliou $\checkmark$, et al. COVID-19 update: the first 6 months of the pandemic. Human Genom. 2020;14(1):48. https://doi.org/10.1186/s40246-020-00298-w.

46. Curtis D. Variants in ACE2 and TMPRSS2 genes are not major determinants of COVID-19 severity in UK Biobank subjects. medRxiv. 2020:2020.05.01. 20085860.

47. Elhabyan A, Elyaacoub S, Sanad E, Abukhadra A, Elhabyan A, Dinu V. The role of host genetics in susceptibility to severe viral infections in humans and insights into host genetics of severe COVID-19: a systematic review. Virus Res. 2020;289:198163. https://doi.org/10.1016/j.virusres.2020.198163.

48. Oh JH, Tannenbaum A, Deasy JO. Identification of biological correlates associated with respiratory failure in COVID-19. BMC Med Genet. 2020;13(1):186

49. Yuan J, Fan D, Xue Z, Qu J, Su J. Co-expression of mitochondrial genes and ACE2 in cornea involved in COVID-19. Invest Ophthalmol Vis Sci. 2020; 61(12):13. https://doi.org/10.1167/iovs.61.12.13

50. Smatti MK, Al-Sarraj YA, Albagha O, Yassine HM. Host genetic variants potentially associated with SARS-CoV-2: a multi-population analysis. Front Genet. 2020;11(1064).

51. Duncan L, Shen H, Gelaye B, Meijsen J, Ressler K, Feldman M, et al. Analysis of polygenic risk score usage and performance in diverse human populations. Nat Commun. 2019;10(1):3328. https://doi.org/10.1038/s41467019-11112-0.

52. Povysil G, Butler-Laporte G, Shang N, Weng C, Khan A, Alaamery M, et al. Failure to replicate the association of rare loss-of-function variants in type I IFN immunity genes with severe COVID-19. medRxiv. 2020:2020.12.18. 20248226.

53. Henzinger $\mathrm{H}$, Barth DA, Klec C, Pichler M. Non-coding RNAs and SARSrelated coronaviruses. Viruses. 2020;12(12).

54. Liu X, Han Z, Yang C. Associations of microRNA single nucleotide polymorphisms and disease risk and pathophysiology. Clin Genet. 2017; 92(3):235-42. https://doi.org/10.1111/cge.12950.

55. Moszyńska A, Gebert M, Collawn JF, Bartoszewski R. SNPs in microRNA target sites and their potential role in human disease. Open Biol. 2017;7(4).

56. Schuler BA, Habermann AC, Plosa EJ, Taylor CJ, Jetter C, Negretti NM, et al. Age-determined expression of priming protease TMPRSS2 and localization of SARS-CoV-2 in lung epithelium. J Clin Invest. 2021;131(1). https://doi.org/1 $0.1172 / \mathrm{JCl} 140766$

57. Blume C, Jackson CL, Spalluto CM, Legebeke J, Nazlamova L, Conforti F, et al. A novel ACE2 isoform is expressed in human respiratory epithelia and is upregulated in response to interferons and RNA respiratory virus infection. Nat Genet. 2021;53(2):205-14. https://doi.org/10.1038/s41588-020-00759-x.

58. Miller LH, Mason SJ, Clyde DF, McGinniss MH. The resistance factor to plasmodium vivax in blacks. The Duffy-blood-group genotype, FyFy. N Engl J Med. 1976;295(6):302-4. https://doi.org/10.1056/NEJM197608052950602.

59. Dean M, Carrington M, Winkler C, Huttley GA, Smith MW, Allikmets R, et al. Genetic restriction of HIV-1 infection and progression to AIDS by a deletion allele of the CKR5 structural gene. Hemophilia growth and development study, multicenter AIDS cohort study, multicenter hemophilia cohort study, san Francisco City cohort, ALIVE study. Science. 1996;273(5283):1856-62. https://doi.org/10.1126/science.273.5283.1856.

60. Lindesmith L, Moe C, Marionneau S, Ruvoen N, Jiang X, Lindblad L, et al. Human susceptibility and resistance to Norwalk virus infection. Nat Med. 2003;9(5):548-53. https://doi.org/10.1038/nm860. 
61. Zeberg $H$, Pääbo S. A genomic region associated with protection against severe COVID-19 is inherited from Neandertals. Proc Natl Acad Sci. 2021; 118(9):e2026309118. https://doi.org/10.1073/pnas.2026309118.

62. Maeda JM, Nkengasong JN. The puzzle of the COVID-19 pandemic in Africa. Science. 2021;371(6524):27-8. https://doi.org/10.1126/science.abf8832.

63. Aluko OM, Lawal SA, Falana MM, Adeagbo AS, ljomone OM. Tackling COVID-19 in Africa: a focus on Nigeria's peculiarities and challenges. Innovation (N Y). 2021;2(1):100078. https://doi.org/10.1016/j.xinn.2021.1 00078.

64. Tso FY, Lidenge SJ, Peña PB, Clegg AA, Ngowi JR, Mwaiselage J, et al. High prevalence of pre-existing serological cross-reactivity against severe acute respiratory syndrome coronavirus-2 (SARS-CoV-2) in sub-Saharan Africa. Int J Infect Dis. 2021;102:577-83. https://doi.org/10.1016/j.ijid.2020.10.104.

65. Uyoga S, Adetifa IMO, Karanja HK, Nyagwange J, Tuju J, Wanjiku P, et al. Seroprevalence of anti-SARS-CoV-2 lgG antibodies in Kenyan blood donors. Science. 2021;371(6524):79-82. https://doi.org/10.1126/ science.abe1916.

66. The Lancet. COVID-19 in Latin America: a humanitarian crisis. Lancet. 2020; 396(10261):1463. https://doi.org/10.1016/S0140-6736(20)32328-X

67. Horwitz, L. (2021). "Timeline: Latin America's race for a COVID-19 vaccine". Retrieved 31/03, 2021, from https://www.as-coa.org/articles/timeline-latin-a mericas-race-covid-19-vaccine.

68. Kelland, K. (2021). "COVID-19: Global donors pledge \$8.8 billion for vaccines". Retrieved 31/03, 2021, from https://www.weforum.org/agenda/2020/06/va ccines-immunisation-poor-countries-coronavirus-covid-gavi.

69. Cohen J. Shots of hope. Science. 2020;370(6523):1392-4. https://doi.org/1 $0.1126 /$ science.370.6523.1392

70. Chan AC, Carter PJ. Therapeutic antibodies for autoimmunity and inflammation. Nat Rev Immunol. 2010;10(5):301-16. https://doi.org/10.1038/ nri2761.

71. Casadevall A, Dadachova E, Pirofski LA. Passive antibody therapy for infectious diseases. Nat Rev Microbiol. 2004;2(9):695-703. https://doi.org/10.1 038/nrmicro974

72. ter Meulen J, Bakker AB, van den Brink EN, Weverling GJ, Martina BE, Haagmans BL, et al. Human monoclonal antibody as prophylaxis for SARS coronavirus infection in ferrets. Lancet. 2004;363(9427):2139-41. https://doi. org/10.1016/S0140-6736(04)16506-9

73. Sui J, Li W, Murakami A, Tamin A, Matthews LJ, Wong SK, et al. Potent neutralization of severe acute respiratory syndrome (SARS) coronavirus by a human mAb to $\mathrm{S} 1$ protein that blocks receptor association. Proc Natl Acad Sci U S A. 2004;101(8):2536-41. https://doi.org/10.1073/pnas.0307140101.

74. Zhu Z, Chakraborti S, He Y, Roberts A, Sheahan T, Xiao X, et al. Potent crossreactive neutralization of SARS coronavirus isolates by human monoclonal antibodies. Proc Natl Acad Sci U S A. 2007;104(29):12123-8. https://doi.org/1 0.1073/pnas.0701000104

75. Corti D, Zhao J, Pedotti M, Simonelli L, Agnihothram S, Fett C, et al. Prophylactic and postexposure efficacy of a potent human monoclonal antibody against MERS coronavirus. Proc Natl Acad Sci U S A. 2015;112(33): 10473-8. https://doi.org/10.1073/pnas.1510199112.

76. Cao Y, Su B, Guo X, Sun W, Deng Y, Bao L, et al. Potent neutralizing antibodies against SARS-CoV-2 identified by high-throughput singlecell sequencing of convalescent patients' B cells. Cell. 2020;182(1):7384.e16.

77. Hansen J, Baum A, Pascal KE, Russo V, Giordano S, Wloga E, et al. Studies in humanized mice and convalescent humans yield a SARS-CoV-2 antibody cocktail. Science. 2020;369(6506):1010-4. https://doi.org/10.1126/science.a bd0827.

78. Noy-Porat T, Makdasi E, Alcalay R, Mechaly A, Levy Y, Bercovich-Kinori A, et al. A panel of human neutralizing mAbs targeting SARS-CoV-2 spike at multiple epitopes. Nat Commun. 2020;11(1):4303. https://doi.org/10.1038/ s41467-020-18159-4.

79. Rogers TF, Zhao F, Huang D, Beutler N, Burns A, He WT, et al. Isolation of potent SARS-CoV-2 neutralizing antibodies and protection from disease in a small animal model. Science. 2020;369(6506):956-63. https://doi.org/10.112 6/science.abc7520.

80. Shi R, Shan C, Duan X, Chen Z, Liu P, Song J, et al. A human neutralizing antibody targets the receptor-binding site of SARS-CoV-2. Nature. 2020; 584(7819):120-4. https://doi.org/10.1038/s41586-020-2381-y.

81. Wan J, Xing S, Ding L, Wang Y, Gu C, Wu Y, et al. Human-IgG-neutralizing monoclonal antibodies block the SARS-CoV-2 infection. Cell Rep. 2020;32(3): 107918. https://doi.org/10.1016/j.celrep.2020.107918.
82. Wec AZ, Wrapp D, Herbert AS, Maurer DP, Haslwanter D, Sakharkar M, et al. Broad neutralization of SARS-related viruses by human monoclonal antibodies. Science. 2020;369(6504):731-6. https://doi.org/10.1126/science.abc7424.

83. Chen P, Nirula A, Heller B, Gottlieb RL, Boscia J, Morris J, et al. SARS-CoV-2 neutralizing antibody LY-CoV555 in outpatients with Covid-19. N Engl J Med. 2020.

84. Lundgren JD, Grund B, Barkauskas CE, Holland TL, Gottlieb RL, Sandkovsky $U$, et al. A neutralizing monoclonal antibody for hospitalized patients with Covid-19. N Engl J Med. 2020;384(10):905-14. https://doi.org/10.1056/ NEJMoa2033130.

85. Weinreich DM, Sivapalasingam S, Norton T, Ali S, Gao H, Bhore R, et al. REGN-COV2, a neutralizing antibody cocktail, in outpatients with Covid-19. N Engl J Med. 2020;384(3):238-51.https://doi.org/10.1056/NEJMoa2035002.

86. Lilly.com (2021). "New data show treatment with Lilly's neutralizing antibodies bamlanivimab (LY-CoV555) and etesevimab (LY-CoV016) together reduced risk of COVID-19 hospitalizations and death by 70 percent". Retrieved 31/03, 2021, from https://investor.lilly.com/news-relea ses/news-release-details/new-data-show-treatment-lillys-neutralizing-a ntibodies.

87. European Medicines Agency (EMA) (2021). Ema.europa.eu "ema.europa.ue". Retrieved 31/03, 2021 from https://www.ema.europa.eu/en/news/emareview-regdanvimab-covid-19-support-national-decisions-early-use.

88. Miersch S, Ustav M, Li Z, Case JB, Ganaie S, Matusali G, et al. Synthetic antibodies neutralize SARS-CoV-2 infection of mammalian cells. bioRxiv. 2020:2020.06.05.137349.

89. Miersch S, Li Z, Saberianfar R, Ustav M, Case JB, Blazer L, et al. Tetravalent SARS-CoV-2 neutralizing antibodies show enhanced potency and resistance to escape mutations. bioRxiv. 2020.

90. Rappazzo CG, Tse LV, Kaku Cl, Wrapp D, Sakharkar M, Huang D, et al. Broad and potent activity against SARS-like viruses by an engineered human monoclonal antibody. Science. 2021;71(6531):823-9. https://doi.org/10.1126/ science.abf4830.

91. Andreano E, Nicastri E, Paciello I, Pileri P, Manganaro N, Piccini G, et al. Extremely potent human monoclonal antibodies from COVID-19 convalescent patients. Cell. 2021;184(7):1821-1835.e16. https://doi.org/10.1 016/j.cell.2021.02.035.

92. De Gasparo R, Pedotti M, Simonelli L, Nickl P, Muecksch F, Cassaniti I, et al. Bispecific IgG neutralizes SARS-CoV-2 variants and prevents escape in mice. Nature. 2021.

93. Brenner S, Jacob F, Meselson M. An unstable intermediate carrying information from genes to ribosomes for protein synthesis. Nature. 1961; 190(4776):576-81. https://doi.org/10.1038/190576a0.

94. Wolff JA, Malone RW, Williams P, Chong W, Acsadi G, Jani A, et al. Direct gene transfer into mouse muscle in vivo. Science. 1990;247(4949 Pt 1):14658. https://doi.org/10.1126/science.1690918.

95. Malone RW, Felgner PL, Verma IM. Cationic liposome-mediated RNA transfection. Proc Natl Acad Sci U S A. 1989;86(16):6077-81. https://doi.org/1 0.1073/pnas.86.16.6077.

96. Pardi N, Hogan MJ, Porter FW, Weissman D. mRNA vaccines - a new era in vaccinology. Nat Rev Drug Discov. 2018;17(4):261-79. https://doi.org/10.103 8/nrd.2017.243.

97. Tourrière $\mathrm{H}$, Chebli $\mathrm{K}$, Tazi J. mRNA degradation machines in eukaryotic cells. Biochimie. 2002;84(8):821-37. https://doi.org/10.1016/s0300-9084(02 )01445-1.

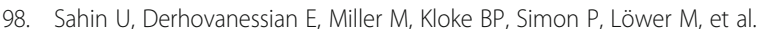
Personalized RNA mutanome vaccines mobilize poly-specific therapeutic immunity against cancer. Nature. 2017;547(7662):222-6. https://doi.org/10.1 038/nature23003.

99. Linares-Fernández S, Lacroix C, Exposito JY, Verrier B. Tailoring mRNA vaccine to balance innate/adaptive immune response. Trends Mol Med. 2020;26(3):311-23. https://doi.org/10.1016/j.molmed.2019.10.002.

100. Martinon F, Krishnan S, Lenzen G, Magné R, Gomard E, Guillet JG, et al. Induction of virus-specific cytotoxic T lymphocytes in vivo by liposomeentrapped mRNA. Eur J Immunol. 1993;23(7):1719-22. https://doi.org/10.1 002/eji.1830230749.

101. Walsh EE, Frenck RW, Falsey AR, Kitchin N, Absalon J, Gurtman A, et al. Safety and immunogenicity of two RNA-based Covid-19 vaccine candidates. N Engl J Med. 2020;383(25):2439-50. https://doi.org/10.1056/NEJMoa2027906.

102. Walsh EE, Frenck R, Falsey AR, Kitchin N, Absalon J, Gurtman A, et al. RNAbased COVID-19 vaccine BNT162b2 selected for a pivotal efficacy study. medRxiv. 2020. 
103. Mulligan MJ, Lyke KE, Kitchin N, Absalon J, Gurtman A, Lockhart S, et al. Phase I/II study of COVID-19 RNA vaccine BNT162b1 in adults. Nature. 2020; 586(7830):589-93. https://doi.org/10.1038/s41586-020-2639-4.

104. Banerii A, Wickner PG, Saff R, Stone CA Jr, Robinson LB, Long AA, et al. mRNA vaccines to prevent COVID-19 disease and reported allergic reactions: current evidence and approach. J Allergy Clin Immunol Pract. 2020.

105. Zhang NN, Li XF, Deng YQ, Zhao H, Huang YJ, Yang G, et al. A thermostable mRNA vaccine against COVID-19. Cell. 2020;182(5):1271-83.e16. https://doi. org/10.1016/j.cell.2020.07.024.

106. Jackson LA, Anderson EJ, Rouphael NG, Roberts PC, Makhene M, Coler RN, et al. An mRNA vaccine against SARS-CoV-2 - preliminary report. N Engl J Med. 2020;383(20):1920-31. https://doi.org/10.1056/NEJMoa2022483.

107. Corbett KS, Flynn B, Foulds KE, Francica JR, Boyoglu-Barnum S, Werner AP, et al. Evaluation of the mRNA-1273 vaccine against SARS-CoV-2 in nonhuman primates. N Engl J Med. 2020;383(16):1544-55. https://doi.org/1 0.1056/NEJMoa2024671.

108. Anderson EJ, Rouphael NG, Widge AT, Jackson LA, Roberts PC, Makhene M, et al. Safety and immunogenicity of SARS-CoV-2 mRNA-1273 vaccine in older adults. N Engl J Med. 2020;383(25):2427-38. https://doi.org/10.1056/ NEJMoa2028436

109. Baden LR, El Sahly HM, Essink B, Kotloff K, Frey S, Novak R, et al. Efficacy and safety of the mRNA-1273 SARS-CoV-2 vaccine. N Engl J Med. 2020

110. Polack FP, Thomas SJ, Kitchin N, Absalon J, Gurtman A, Lockhart S, et al. Safety and efficacy of the BNT162b2 mRNA Covid-19 vaccine. N Engl J Med. 2020;383(27):2603-15. https://doi.org/10.1056/NEJMoa2034577.

111. Widge AT, Rouphael NG, Jackson LA, Anderson EJ, Roberts PC, Makhene M, et al. Durability of responses after SARS-CoV-2 mRNA-1273 vaccination. N Engl J Med. 2020;384(1):80-2. https://doi.org/10.1056/NEJMc2032195.

112. Thompson MG, Burgess JL, Naleway AL, Tyner HL, Yoon SK, Meece J, et al. Interim estimates of vaccine effectiveness of BNT162b2 and mRNA-1273 COVID-19 vaccines in preventing SARS-CoV-2 infection among health care personnel, first responders, and other essential and frontline workers - eight U.S. locations, December 2020 - march 2021. MMWR Centers Dis Contr Prev (CDC) Early Release. 2021;70.

113. Mascola JR, Fauci AS. Novel vaccine technologies for the 21st century. Nat Rev Immunol. 2020;20(2):87-8. https://doi.org/10.1038/541577-019-0243-3.

114. Blanchard EL, Vanover D, Bawage SS, Tiwari PM, Rotolo L, Beyersdorf J, et al. Treatment of influenza and SARS-CoV-2 infections via mRNA-encoded Cas13a in rodens. Nat Biotechnol. 2021.

115. Di Giorgio S, Martignano F, Torcia MG, Mattiuz G, Conticello SG. Evidence for host-dependent RNA editing in the transcriptome of SARS-CoV-2. Sci Adv. 2020;6(25):eabb5813. https://doi.org/10.1126/sciadv.abb5813.

116. Xie X, Liu Y, Liu J, Zhang X, Zou J, Fontes-Garfias CR, et al. Neutralization of SARS-CoV-2 spike 69/70 deletion, E484K, and N501Y variants by BNT162b2 vaccine-elicited sera. bioRxiv. 2021.01.27.427998.

117. Wang Z, Schmidt F, Weisblum Y, Muecksch F, Barnes CO, Finkin S, et al. mRNA vaccine-elicited antibodies to SARS-CoV-2 and circulating variants. bioRxiv.2021.01.15.426911.

118. Hoffmann M, Kleine-Weber $H$, Schroeder $S$, Kruger $N$, Herrler T, Erichsen $S$, et al. SARS-CoV-2 cell entry depends on ACE2 and TMPRSS2 and is blocked by a clinically proven protease inhibitor. Cell. 2020;181(2):271-280.e8. https://doi.org/10.1016/j.cell.2020.02.052.

119. Novelli G, Liu J, Biancolella M, Alonzi T, Novelli A, Patten JJ, et al. Inhibition of HECT E3 ligases as potential therapy for COVID-19. Cell Death Dis. 2021; 12(4):310. https://doi.org/10.1038/s41419-021-03513-1.

\section{Publisher's Note}

Springer Nature remains neutral with regard to jurisdictional claims in published maps and institutional affiliations.

Ready to submit your research? Choose BMC and benefit from:

- fast, convenient online submission

- thorough peer review by experienced researchers in your field

- rapid publication on acceptance

- support for research data, including large and complex data types

- gold Open Access which fosters wider collaboration and increased citations

- maximum visibility for your research: over $100 \mathrm{M}$ website views per year

At $\mathrm{BMC}$, research is always in progress.

Learn more biomedcentral.com/submissions 